\title{
Differences in throughfall and net precipitation between soybean and transitional tropical forest in the southern Amazon, Brazil.
}

Frank Bäse $^{\mathrm{a}}$, Helmut Elsenbeer ${ }^{\mathrm{a}}$, Christopher Neill ${ }^{\mathrm{b}}$ and Alex V. Krusche ${ }^{\mathrm{c}}$

\author{
a Institut für Erd- und Umweltwissenschaften, Universität Potsdam, Potsdam, Germany, \\ tel: +49 331 9772242, fax: +49 331 9772068, email: Frank.Baese@uni-potsdam.de \\ ${ }^{\mathrm{b}}$ The Ecosystems Center, Marine Biological Laboratory, Woods Hole, MA 02543, USA \\ ${ }^{\mathrm{c}}$ Laboratório de Ecologia Isotópica, Centro de Energia na Agricultura, University of São Paulo, \\ Piracicaba, SP, Brazil
}

\section{Abstract}

The expansion of soybean cultivation into the Amazon in Brazil has potential hydrological effects at local to regional scales. To determine the impacts of soybean agriculture on hydrology, a comparison of net precipitation (throughfall, stemflow) in undisturbed tropical forest and soybean fields on the southern edge of the Amazon Basin in the state of Mato Grosso is needed This study measured throughfall with troughs and stemflow with collar collectors during two rainy seasons. The results showed that in forest $91.6 \%$ of rainfall was collected as throughfall and $0.3 \%$ as stemflow, while in soybean fields with two-month old plants, $46.2 \%$ of rainfall was collected as throughfall and $9.0 \%$ as stemflow. Hence, interception of precipitation in soybean fields was far greater than in intact forests.

Differences in throughfall, stemflow and net precipitation were found to be mainly associated with differences in plant structure and stem density in transitional forest and soybean cropland. Because rainfall interception in soybean fields is higher than previously believed and because both the area of cropland and the frequency of crop cycles (double cropping) are increasing rapidly, interception needs to be reconsidered in regional water balance models 
when consequences of land cover changes are analyzed in the Amazon soybean frontier region. Based on the continued expansion of soybean fields across the landscape and the finding that net precipitation is lower in soy agriculture, a reduction in water availability in the long term can be assumed.

Keywords: throughfall, net precipitation, stemflow, soybean, tropical forest

\section{Introduction}

The widespread clearing of tropical forest for agriculture has profound effects on the water budget of the land surface and the amount of rainfall returned to the atmosphere by evaporation and transpiration. Changes in leaf area, albedo, surface temperature and latent heat flux as well as different water use strategies by tropical forest trees compared with pasture grasses or crops lead to changes in evapotranspiration (Pongratz et al., 2006). In the Amazon Basin, evapotranspired (recycled) water accounts for 25 to $50 \%$ of precipitation (Eltahir and Bras, 1994; Hutyra et al., 2005; Marengo, 2006). As much as one-third of this recycled water originates from water intercepted from vegetation surfaces (Lawrence et al., 2007). Because of the decrease in the atmospheric transport of water vapor into the Amazon Basin (Costa and Foley, 1999), internally recycled precipitation is even more important and detailed knowledge of the interception capacities of dominant land cover types in the Amazon region is needed for water budget calculations (Czikowsky and Fitzjarrald, 2009). Large-scale land-use changes are accompanied by alterations in regional climate and the hydrological cycle in the Amazon basin (Marengo, 2006). Quantitative information about net precipitation, or the fraction of precipitation remaining after evaporation from surfaces, is needed to assess the consequences of deforestation and agricultural expansion on water budgets and for the modeling of regional water balances. 
Exemplary for the southern Brazilian Amazon also known as the "Arc of Deforestation", in the state of Mato Grosso the expansion rate of soybean cropland has outpaced the expansion rate for pasture on deforested areas (Morton et al., 2006). In Mato Grosso soybean production doubled in area from 3.1 million ha to 6.2 million ha between 2000 and 2010 (CONAB - Companhia Nacional de Abastecimento, 2011). Most expansion of soybean cultivation occurred on land that was already deforested and used as pasture (Brown et al., 2005; Macedo et al., 2012). While the hydrological consequences of conversion of Amazon forest to pasture received considerable attention (De Moraes et al., 2006; Germer et al., 2010a; Hasler and Avissar, 2007), the hydrological effects of soybean cropland are less well known and deserve increasing attention because of the rapid expansion of soybean cropland area. Recent large scale climate and biosphere model studies of climate response to the expansion of cropland in the southern Amazon (Costa et al., 2007; Pongratz et al., 2006; Sampaio et al., 2007) concluded that conversion of forest to soybean yields an increase in near surface temperature and a decrease in evapotranspiration and precipitation due to a higher albedo and cloud-radiative feedbacks. Nevertheless, to strengthen the credibility of such models additional field experiments are needed.

Throughfall studies in soybean plantations are sparse (Bo et al., 2008; Lull, 1964; Savabi and Stott, 1994; Zhang et al., 1999) and uncertainties in the total water input and the role of stemflow are huge (Lilienfein and Wilcke, 2004). In addition, most of what is known about throughfall, stemflow, and net precipitation in the Amazon forest is based on studies in the northern (Ubarana, 1996; Tobón Marin et al., 2000; Klinge et al., 2001; Oliveira et al., 2008), western (Elsenbeer et al., 1994; Ubarana, 1996; Germer et al., 2010a, 2006), and central Amazon Basin (Lloyd and de O. Marques Filho, 1988; Cornu et al., 1998; Cuartas et al., 2007; Czikowsky, 2009) and floodplain forest (Filoso et al., 1999). Although a few studies were conducted in the cerrado (forest savanna) (Lima and Nicolielo, 1983; Lilienfein and Wilcke, 2004) and in a dry forest (Jetten, 1996), the site of the most intense conversion of 
forest to soybean is the transitional forest-cerrado ecotone of the southern Amazon Basin which occupies an area of 414,000 km² (Marimon et al., 2006; WWF, 2012) and has yet to receive due attention. Transitional forest is characterized by a dense understory as well as lower species diversity, tree height and leaf area index (LAI) than the Terra Firme forest (non flooded tropical forest) of the Amazon Basin (Balch et al., 2008; Ivanauskas et al., 2004; De Oliveira and Mori, 1999).

The goal of this paper is to quantify the amount of net precipitation in transitional forest and soybean fields. Based on observations of throughfall and stemflow over two rainy seasons, implications of hydro-meteorological consequences were drawn. Furthermore, this study aims to contribute to the discussion of ecological cost of the intensification of agriculture due to soybean expansion and double cropping.

2 Materials and methods

\subsection{Study sites}

The study area is located in the northeast of Mato Grosso, Brazil at Tanguro Ranch in

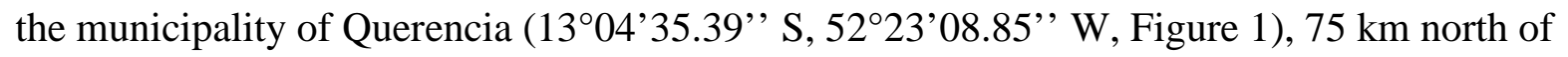
Canarana. The ranch lies $370 \mathrm{~m}$ above sea level on Tertiary sediment plain, covered by Oxisols (Latossolo Vermelho according to the Brazilian classification) (RADAM, 1981). Land use at the ranch during the duration of the study was dominated by transitional forest and soybean (Glycine max) plantations in roughly equal areas (Figure 1). The climate is classified as tropical wet and dry (Aw, Köppen, 1936) with a rainy season from September to the end of April accounting for 95.6\% of the mean annual precipitation (MAP). In addition to the seasonal changes in mean monthly accumulated precipitation, there are strong differences between the rainy and dry season in terms of the daily minimum, average, and maximum monthly temperatures as well as the daily average relative humidity (Table 1). In the period 
between 1987 and 2008 the MAP recorded at Tanguro Ranch was $1884 \mathrm{~mm}$. The mean annual temperature was $25.4{ }^{\circ} \mathrm{C}(2004-2010)$.

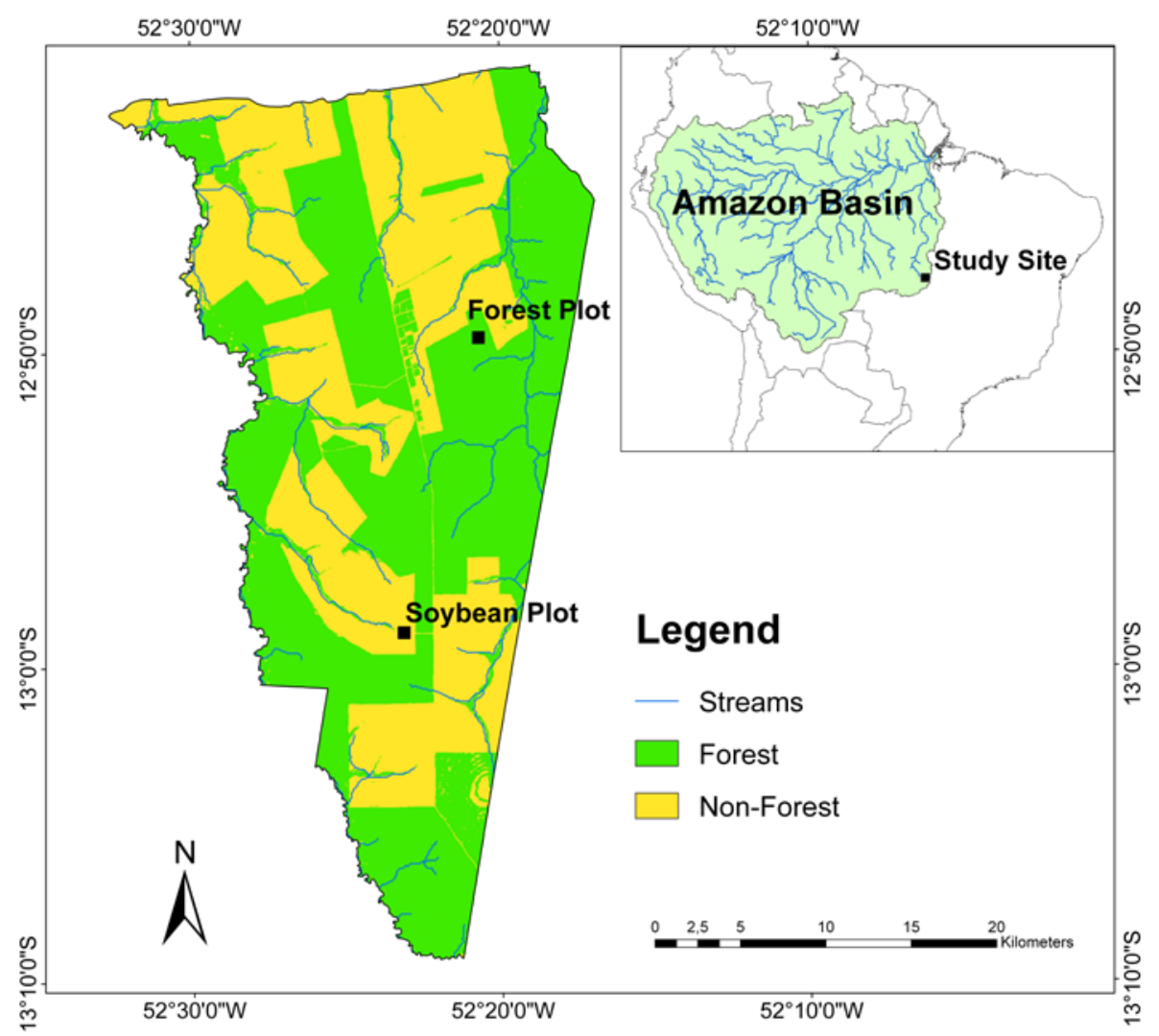

Figure 1: Land cover of the Tanguro Ranch based on a Landsat Thematic Mapper satellite image from June $23^{\text {rd }} 2001$ (classified by Paul Lefebvre). Non-Forest area was recorded as soybean cropland by farm records from 2008.

Table 1: Summary of monthly precipitation, minimum, average and maximum temperature and mean relative humidity measured at Tanguro Ranch.

Jan. Feb. Mar. Apr. May Jun. Jul. Aug. Sep. Oct. Nov. Dec.

\begin{tabular}{lcccccccccccc}
\hline Precip. mean [mm] & 349 & 299 & 267 & 143 & 31 & 4 & 1 & 4 & 44 & 175 & 260 & 308 \\
Temp. Min. $\left[{ }^{\circ} \mathrm{C}\right]^{\mathrm{b}}$ & 21.6 & 21.8 & 21.6 & 21.1 & 18.9 & 16.3 & 15.5 & 15.8 & 18.6 & 22.0 & 21.9 & 21.7 \\
Temp. avg. $\left[{ }^{\circ} \mathrm{C}\right]^{\mathrm{b}}$ & 25.7 & 25.3 & 25.1 & 25.4 & 25.1 & 24.3 & 24.4 & 25.6 & 27.2 & 26.7 & 25.7 & 24.7 \\
$\begin{array}{l}\text { Temp. max. }\left[{ }^{\circ} \mathrm{C}\right]^{\mathrm{b}} \\
\text { Rel. Hum. mean }\end{array}$ & 31.6 & 31.0 & 30.7 & 32.0 & 32.5 & 33.3 & 33.9 & 35.4 & 36.1 & 33.1 & 31.4 & 29.6 \\
{$[\%]^{\mathrm{b}}$} & 84.2 & 88.5 & 86.0 & 83.3 & 74.4 & 65.4 & 58.4 & 51.0 & 51.4 & 73.3 & 82.4 & 88.0 \\
\hline
\end{tabular}

${ }^{\mathrm{a}}$ Mean precip. 1987-2008, manual daily measurements provided by Grupo A. Maggi.

${ }^{\mathrm{b}}$ Mean based on daily values, measured at Tanguro Ranch, Darro climate station from 2004-2010 (data from

IPAM). Only month having no more than 5 missing days were used for calculation. 


\subsection{Sampling}

In the forest, a 1 ha plot was established where all the sampling was conducted.

Because of the regular structure of the soybean fields, two plots of 10 x 10 m were randomly placed in the 2008-2009 rainy season and one plot in the 2009-2010 rainy season. All plots, forest and soybean, were respectively $430 \mathrm{~m}$ and $170 \mathrm{~m}$ from the forest boundary to avoid edge effects. Soybeans were planted on 20 December 2008 and 3 December 2009 and harvested on 11 April 2009 and 6 April 2010, respectively (growth period of 113 d and 124 d, respectively). To ensure throughfall was monitored under conditions of similar canopy cover and plant height, measurements in the soybean fields were conducted between 50 and 100 days after emergence. While throughfall was monitored in both rainy seasons (2008-2009 and 2009-2010) stemflow was measured only in the rainy season of 2009-2010 (Table 2). All samplers were measured and emptied on a daily basis.

Table 2: Sampling periods of throughfall and stemflow in the forest and soybean site during the rainy season 2008/2009 and 2009/2010.

\begin{tabular}{llcccc}
\hline & & \multicolumn{2}{c}{$2008 / 09$} & \multicolumn{2}{c}{$2009 / 10$} \\
& & date & \# evt. & date & \# evt. \\
\hline \multirow{2}{*}{ Forest } & Throughfall & 26. Oct.-07. Apr. & 28 & 01. Nov.-23. Mar. & 37 \\
& Stemflow & --- & --- & 06. Feb.-23. Mar. & 22 \\
Soybean & Throughfall & 24. Feb.-27. Mar. & 20 & 22. Jan.-09. Mar. & 24 \\
& Stemflow & --- & --- & 22. Jan.-09. Mar. & 18 \\
\hline
\end{tabular}

\subsection{Vegetation characteristics}

The 1 ha forest plot represented an old-growth undisturbed transitional forest. Diameter at breast height (dbh, $130 \mathrm{~cm}$ above the ground) of all trees and lianas $\geq 5 \mathrm{~cm}$ dbh was measured to describe forest structure. In a nearby transitional forest site (approximately $30 \mathrm{~km}$ away) Balch et al. (2008) determined the mean canopy height of trees $\geq 40 \mathrm{~cm} \mathrm{dbh}$ was $20 \pm 1$ (SE) m. Following the procedure described by Balch et al. (2008) the leaf area index (LAI) was measured using two LAI-2000 Plant Canopy Analyzers in differential mode 
(LI-COR Inc., Lincoln, NE, USA; Welles, 1990). LAI measurement series were made five times during the rainy season of 2008-2009 (Sep, Nov, Dec, Mar, Apr).

At the Tanguro Ranch soybean was planted at a $0.5 \mathrm{~m}$ row spacing with approximately 10 plants per $\mathrm{m}$, resulting in a density of 27 plants per $\mathrm{m}^{2}$. In the 2008-2009 rainy season the LAI was measured 74, 81, 86, 94 and 100 days after emergence in the soybean plot 1 using two LAI-2000 Plant Canopy Analyzers.

\subsection{Throughfall and gross precipitation}

The throughfall collectors were 0.15 x 1.50 m PVC troughs with a collection surface of $980 \mathrm{~cm}^{2}$ (Germer et al., 2006). In the forest, 13 collectors were randomly distributed and placed $1 \mathrm{~m}$ above the ground. To avoid evaporation, the collected water drained into $20 \mathrm{~L}$ plastic canisters. Collected water was measured with graduated cylinders. During the rainy seasons of 2008-2009 and 2009-2010 64 throughfall measurements (events) were captured in the forest.

In the soybean field, collectors of the same design were placed on the ground between and across the rows (Figure 2), with the surface of the troughs $20 \mathrm{~cm}$ above the ground. Four such collectors were placed in each of the two soybean plots in the 2008-2009 season, and eight were placed in the single plot in 2009-2010. Because of the short growing season of soybean only 44 rainfall events were sampled during the two seasons.

Gross precipitation was collected by a reference trough at a distance of $430 \mathrm{~m}$ from the measurement plot in the forest site and $20 \mathrm{~m}$ from the forest boundary. In the soybean field the reference gauge was located directly in each of the measurement plots above the canopy (Figure 2). To measure rainfall intensities Onset data logging rain gauges (resolution: 0.254 mm) equipped with HOBO Event Loggers (Onset Computer Corporation, Massachusetts, USA) were installed at each site. Furthermore, daily manual rainfall measurements at Tanguro 
Ranch from 1987 to 2008, provided by Groupo A. Maggi, were used to calculate mean monthly rainfall.
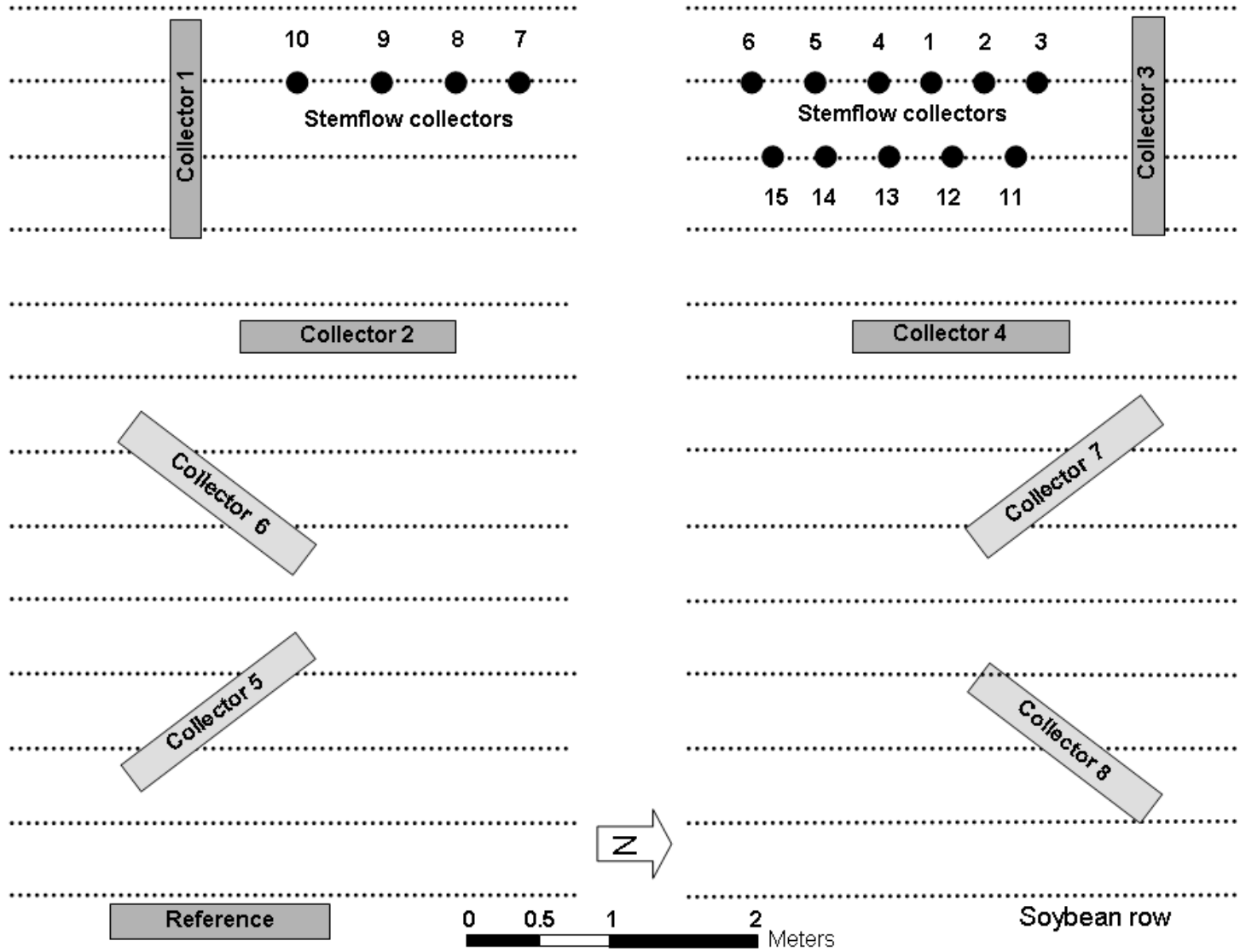

Soybean row

Figure 2: Arrangement of the throughfall and stemflow collectors in the soybean plots. The darker collectors represent the arrangement of the collectors in the 2008-2009 rainy season. In the 2009-2010 rainy season all collectors were used.

\subsection{Stemflow}

In addition to crown size, leave shape and orientation, branch angle and flow path obstructions, the wettability and thickness of bark has a substantial effect on stemflow yield (Crockford and Richardson, 1990). Thus, all the trees in the forest plot were classified as having rough or smooth bark. Both tree classes were subdivided according their dbh into classes of $5 \mathrm{~cm}-10 \mathrm{~cm}, 10 \mathrm{~cm}-20 \mathrm{~cm}$, and $\geq 20 \mathrm{~cm}$. Furthermore, lianas $\geq 5 \mathrm{~cm}$ dbh were measured and allocated to a single class. In each class, five randomly selected stems were 
equipped with a collar type sampler (35 samples in total, from five stems in each of the seven classes). The stemflow collars consisted of a $5 \mathrm{~cm}$ flexible PVC strip nailed to the trunk in a downward spiral that circled the stem 1.5 times. A maximum opening of $2 \mathrm{~cm}$ was applied to avoid direct rain input. The collars were mounted at breast height and sealed to the stem with neutral silicone sealant. At the lower end of the collars a funnel was mounted and covered with plastic bags to avoid direct rain input. From the funnel, a hose drained the stemflow into 20 L plastic canisters. During the period of 29.01.2010 to 23.03.2010 stemflow was sampled from 27 rainfall events.

Stemflow volume of a tree class $j$ in $\mathrm{mm}\left(\mathrm{pt}_{j}\right)$ was calculated following the equation used by Dezzeo and Chacón (2006):

$$
p t=\sum_{j=1}^{n} v i / A i^{*} A j / A
$$

where $n$ is the number of tree classes, $v_{i}$ is the volume of the measured stemflow in liters of a individual tree $i, \mathrm{~A}_{i}$ is the basal area of the measured tree in $\mathrm{m}^{2}$ and $\mathrm{A}_{j}$ is the basal area of all the trees of the class the sampled tree belongs to within the plot (A) in $\mathrm{m}^{2}$.

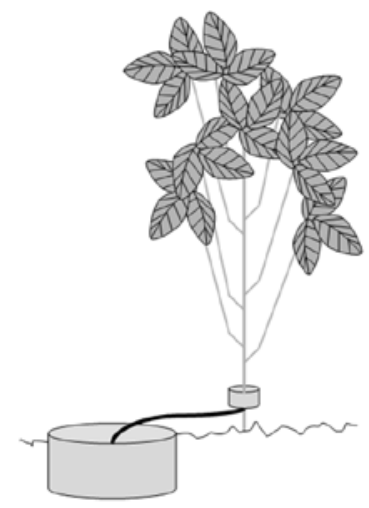

Figure 3: Experimental set-up of stemflow measurements on soybean plants using the collar method.

In the soybean field, stemflow was measured with 15 collar collectors. Flexible $3 \mathrm{~cm}$ plastic strips were wrapped around the stems to create small funnels fixed with duct tape and sealed 
with neutral silicone. To drain the funnel, small hoses (5 mm diameter) were used (Figure 3). Stemflow was collected in $500 \mathrm{~mL}$ PVC bottles which were dug into the ground. These collar collectors were used to intercept stemflow in corn (Bui and Box Jr, 1992; Lamm and Manges, 2000). The stemflow collars affect the growth of soybeans negatively, so the collars were reinstalled on new plants at two week intervals. Nevertheless, 18 stemflow events were sampled between 22.01.2010 and 08.03.2010. Stem diameter of the sampled soybean plants was measured before installation.

2.6 Net precipitation and comparison with throughfall

For the quantification of net precipitation, the sum of throughfall and stemflow was calculated. Therefore, only precipitation events were used for which both throughfall and stemflow data were collected. Results were examined at two temporal resolutions. First, as a broader approach, all measurements during the observation period were accumulated as total throughfall, total stemflow, and total net precipitation. Second, individual events were used to compare the two land cover types with respect to throughfall, stemflow, and net precipitation.

Furthermore, the mean annual intercepted rainfall of forest, as the difference between net and gross precipitation (MAP) was determined. Because of the short growing season of soybean, the difference between gross and net precipitation of the measured period (February and March) was calculated using mean monthly precipitation. The sum of the intercepted rainfall for March and February was assumed to be a good approximation of the annual interception in soybean.

\section{Results}

\subsection{Vegetation characteristics}

In the forest hectare plot 1392 individual stems (including 71 lianas) with $\mathrm{dbh} \geq 5 \mathrm{~cm}$ were identified (Table 3). The plot was dominated by trees and lianas with a dbh between 5 
and $10 \mathrm{~cm}$ (57.1\% of all stems). Trees of this dbh class with smooth bark are most frequent and comprised $48.4 \%$ of all stems. The cumulative basal area of all trees was $25 \mathrm{~m}^{2}$ while stems $\geq 20 \mathrm{~cm}$ dbh (179 stems) contributed $60 \%$ of the basal area. The mean stem diameter of soybean plants was $1 \mathrm{~cm}$ during the observation period, which summed to a basal area of 21.3 $\mathrm{m}^{2}$ ha $^{-1}$.

Table 3: Number of stems in the 1 ha forest plot classified by diameter at breast height, type of bark and lianas as well as their cumulative basal area.

\begin{tabular}{lcccc} 
& \multicolumn{3}{c}{ number of stems per ha } & total \\
dbh $[\mathrm{cm}]$ & $5<10$ & $10<20$ & $\geq 20$ & \\
\hline rough bark & 57 & 100 & 43 & 200 \\
smooth bark & 674 & 311 & 136 & 1121 \\
liana & 64 & 7 & 0 & 71 \\
\hline total & 795 & 418 & 179 & 1392 \\
& & basal area $\left[\mathrm{m}^{2} / \mathrm{ha}\right]$ & & \\
dbh $[\mathrm{cm}]$ & $5<10$ & $10<20$ & $\geq 20$ & 4.56 \\
\hline rough bark & 0.25 & 1.60 & 2.71 & 20.08 \\
smooth bark & 2.67 & 4.63 & 12.78 & 0.30 \\
liana & 0.23 & 0.07 & 0 & 24.94 \\
\hline total & 3.15 & 6.30 & 15.49 & \\
\hline
\end{tabular}

LAI measured 74, 81, 86, 94 and 100 days after emergence in the soybean field were 4.2, 4.3, 4.2, 3.7 and 3.5, respectively (Figure 4). In the forest LAI measurements conducted in Sep. 2008, Nov. 2008, Dec. 2008, Mar. 2009 and Apr. 2009 were 4.5, 5.9, 4.3, 4.9 and 4.2, respectively. Mean LAI was $4.8( \pm 0.3, \mathrm{SE})$ in the forest vs. $4.0( \pm 0.2, \mathrm{SE})$ in the soybean field. While in the soybean a clear decrease of LAI towards the end of the growing season was observed, in the forest no trend was found during the rainy season. 


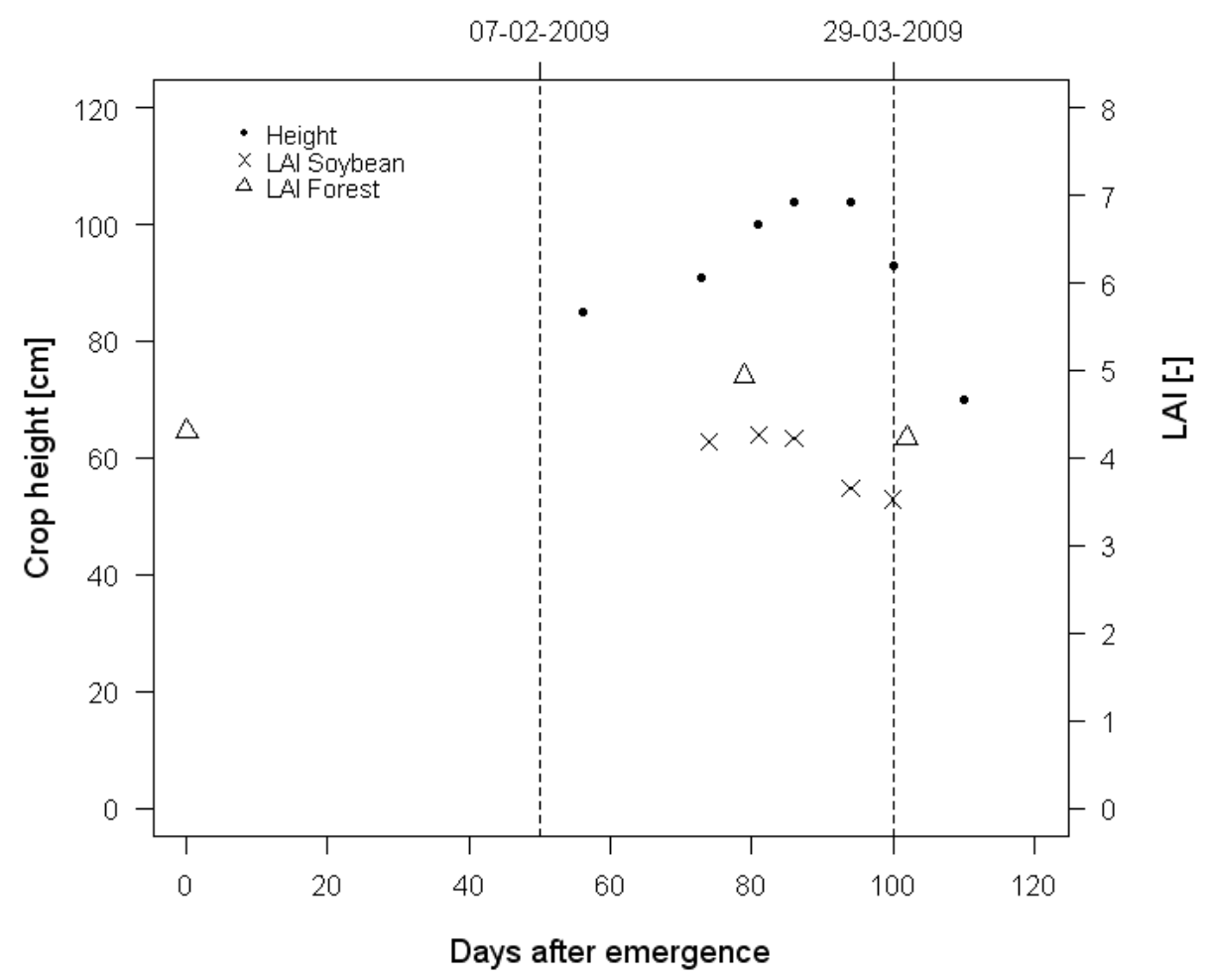

Figure 4: Soybean canopy height [cm] and LAI [-] throughout the growing season in relation to LAI [-] in the forest. The vertical lines define the period of throughfall and stemflow measurements in the soybean plots (between 50 and 100 days after emergence).

3.2 Throughfall and gross precipitation

Total gross precipitation of all events in the forest site amounted to $1314 \mathrm{~mm}$, and $1203 \mathrm{~mm}$ of the rain was measured as throughfall (91.6\%). In the soybean field $314 \mathrm{~mm}$ (46.2\%) of the accumulated rainfall events (678 $\mathrm{mm}$ gross precipitation) were measured as throughfall. 


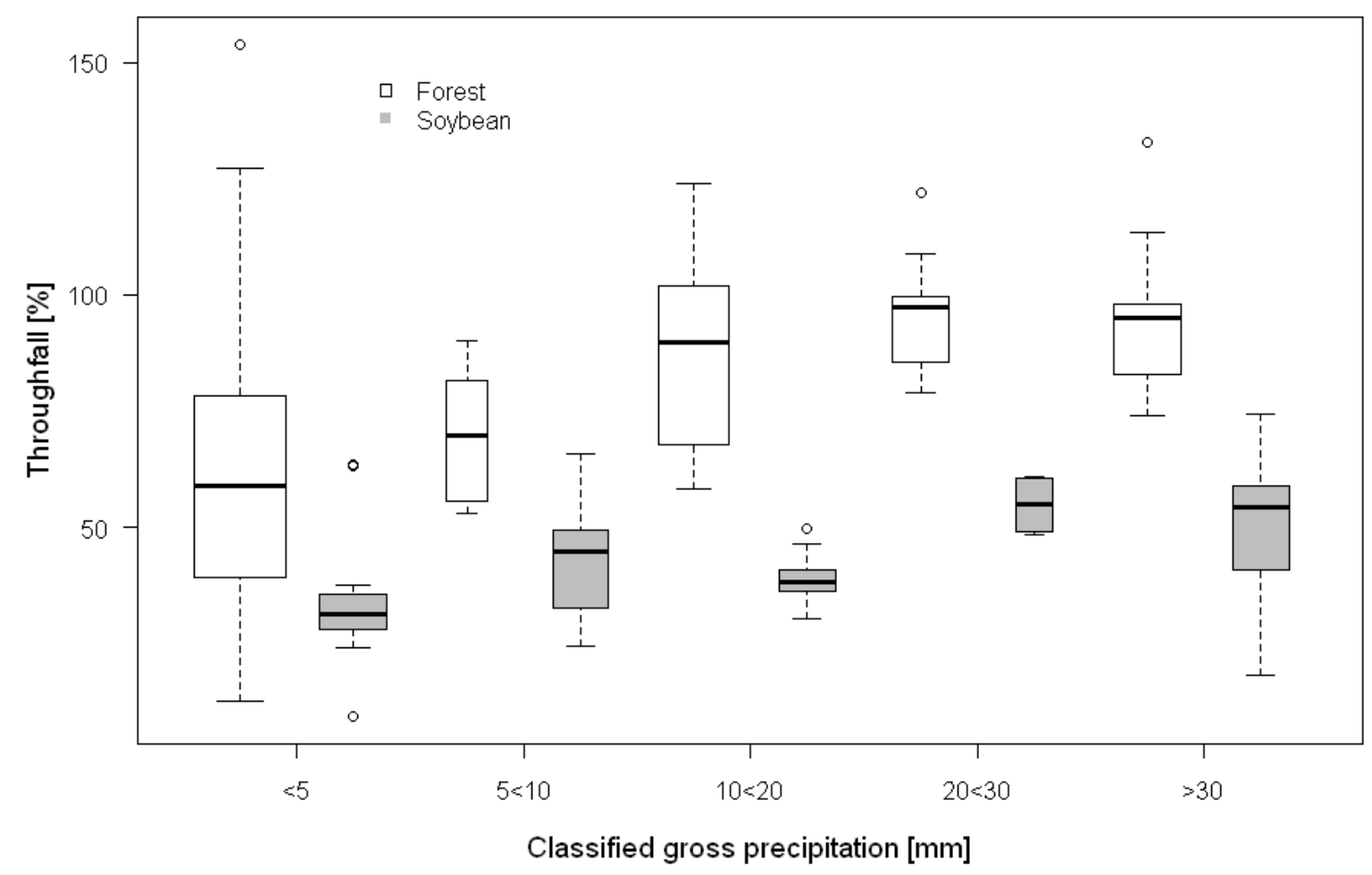

Figure 5: Throughfall [\%] as a function of rainfall event size at Tanguro Ranch, Brazil showing single events summarized in gross precipitation classes. The width of the boxplots is proportional to the number of events (n) in each gross precipitation class, $n_{\text {Forest }}=24,4,14,9$, 13 and $\mathrm{n}_{\text {Soybean }}=13,9,9,4,9$, respectively. The bold line in the middle of the boxes represents the median of the samples. The surrounding boxes illustrate the interquartile range, while the whiskers reflect the extreme values within 1.5 times the interquantile range. Values exceeding this threshold are marked as outliers in the shape of an open circle.

The percentage of throughfall increased with the event size of precipitation in the forest more than in the soybean plots (Figure 5). Because of the distance between the measurement plot and the precipitation reference site in the forest, the spread of relative throughfall values was wider, especially during small events $(<5 \mathrm{~mm})$. In the forest, 11 events produced more throughfall than gross precipitation (Figure 6), whereas in the soybean site all throughfall measurements were less than gross precipitation (Figure 6). The standard 
error (SE) of the mean relative thoughfall during the observation period in the soybean field (SE: 2.1) was approximately half the SE in the forest site (4.0), which reflects the low degree of change in the canopy structure of the soybean plantation during the observation period. There was no relationship between the amount of throughfall and mean rainfall intensity nor were there any temporal trends in throughfall in the forest or in the soybean field.
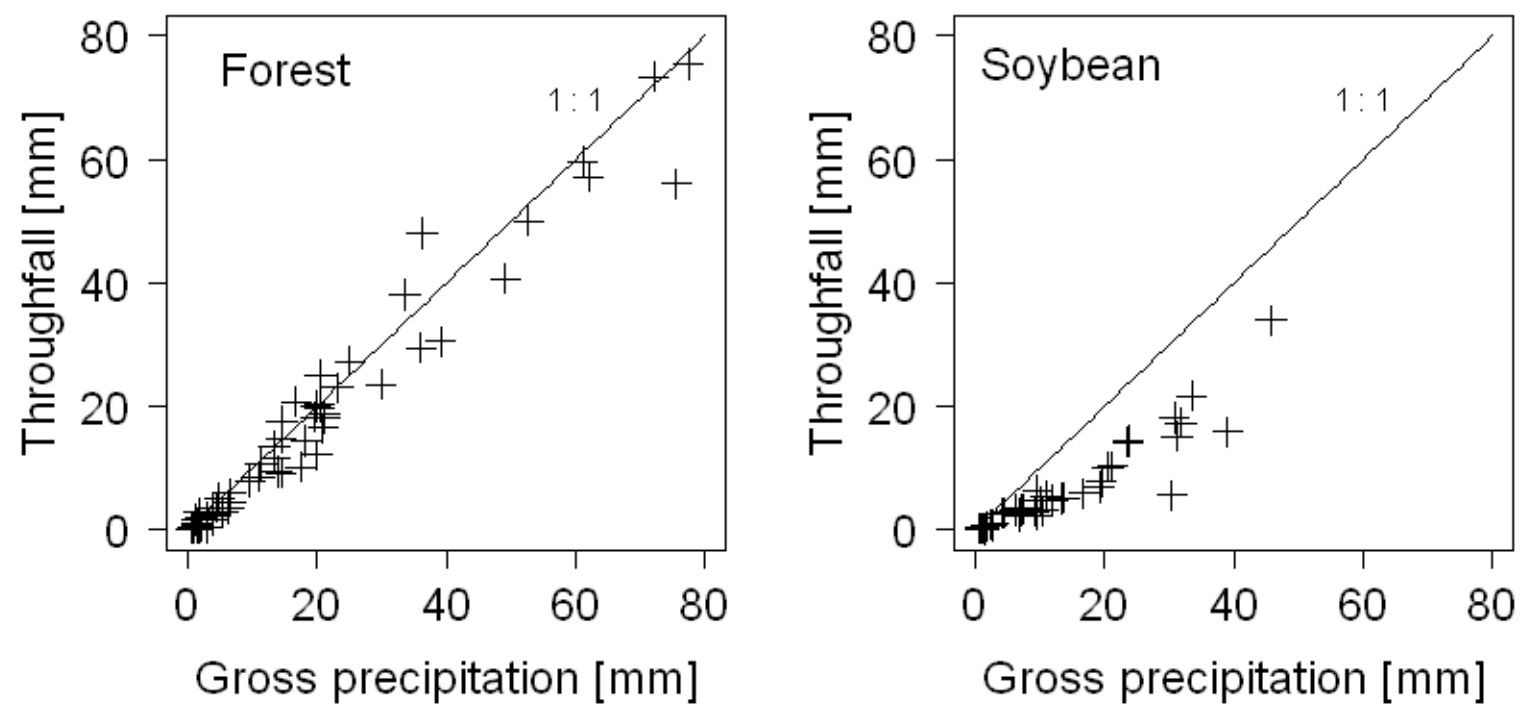

Figure 6: Throughfall events [mm] plotted against gross precipitation [mm] in the transitional forest $(n=64)$ and in the soybean $(n=44)$. A one to one line is also shown.

\subsection{Stemflow}

In the forest, stemflow for 27 rainfall events with a total of $385.0 \mathrm{~mm}$ were captured; $1.3 \mathrm{~mm}$ of this precipitation were collected as stemflow (0.33\%). During the study period rainfall events ranging from 0.9 to $72.1 \mathrm{~mm}$ were measured. Precipitation events $<14 \mathrm{~mm}$ produced almost no stemflow, whereas the amount of stemflow increased proportionally to the amount of precipitation for events $>14 \mathrm{~mm}$. Stemflow between the size and bark morphology classes differed considerably (Figure 7). Stems with smooth bark contributed the most to stemflow, and the proportion of stemflow decreased with increased stem diameter. No 
significant differences in stemflow could be observed between classes of rough-barked stems or between rough-barked stems and lianas (Figure 7, 95\% confidence intervals cross zero). Stemflow in the soybean field was greater than in the forest and developed even during small precipitation events. The collected rainfall events totalled $328.4 \mathrm{~mm}$ and ranged from 0.6 to $45.7 \mathrm{~mm}$. These events produced $29.7 \mathrm{~mm}$ of stemflow (9.0\%). The amount of stemflow varied widely in relation to gross precipitation $\left(\mathrm{R}^{2}=0.37\right)$.

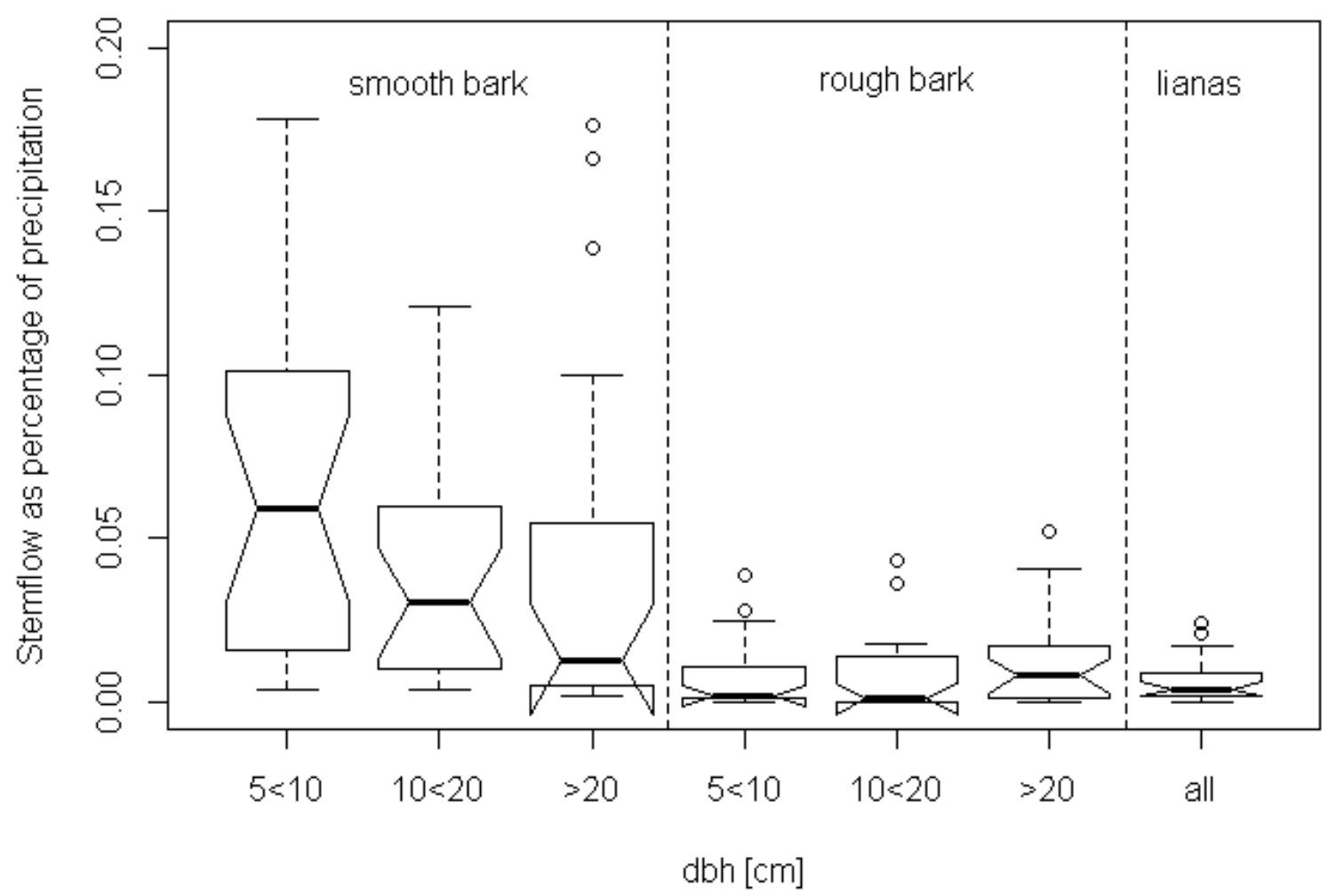

Figure 7: Stemflow as a percentage of gross grecipitaion in the transitional forest separated by class $(n=27)$.

\subsection{Net Precipitation and interception}

In the forest $94.2 \%$ of precipitation was measured as net precipitation, based on 27 events (throughfall and stemflow). Net precipitation in soybean was $57.2 \%$ of gross precipitation based on 18 events. By applying $1884 \mathrm{~mm}$ mean annual precipitation, the annual 
intercepted rainfall in the forest was $109.3 \mathrm{~mm}$, where interception was calculated as the difference between gross precipitation and net precipitation. In soybean fields, the intercepted rainfall was $140.5 \mathrm{~mm}$ during the measurement period of 2010 (46 days), which indicates an average of $3.1 \mathrm{~mm}$ of precipitation was lost by evaporation each day.

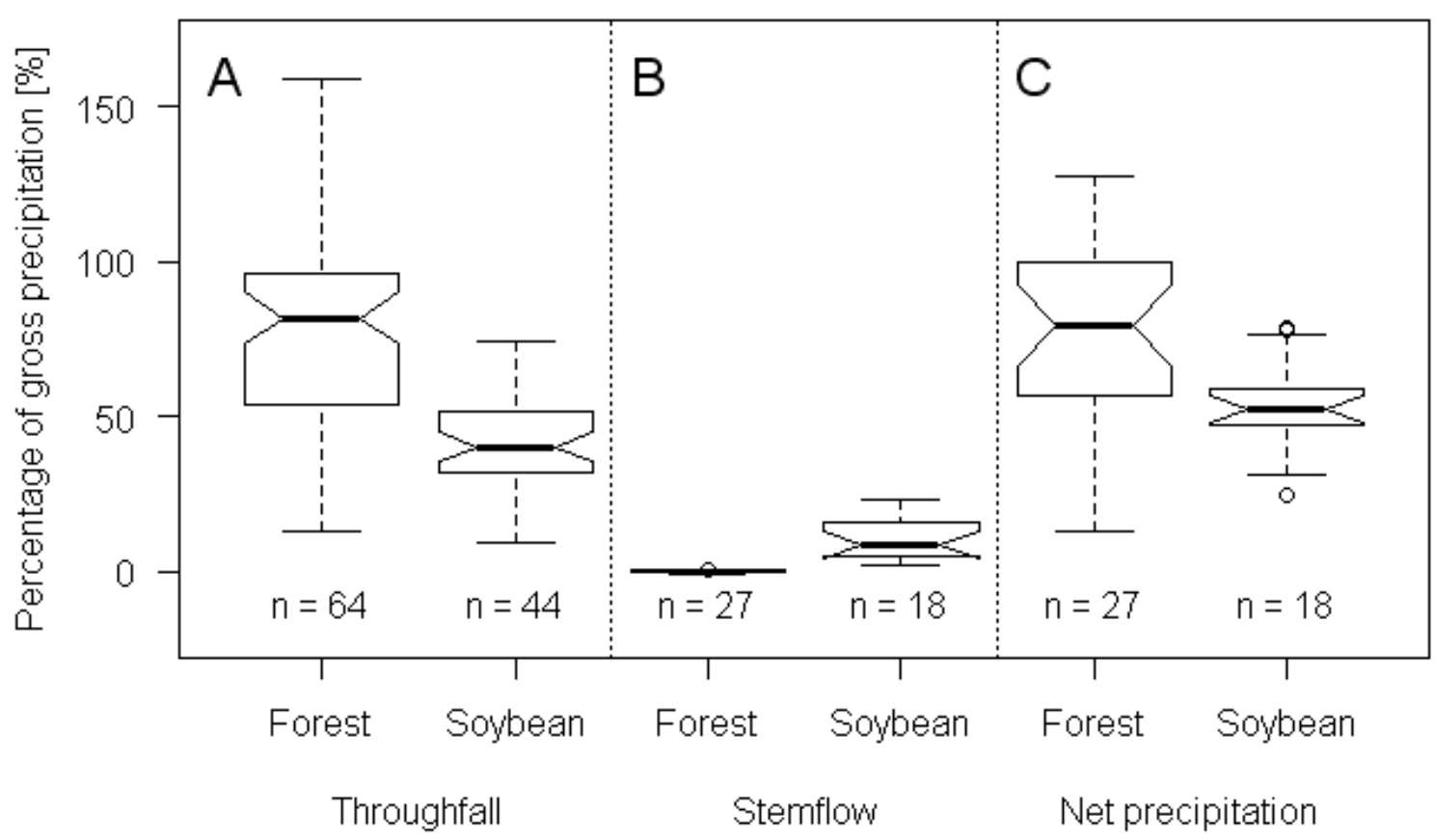

Figure 8: Throughfall (A), stemflow (B) and net precipitation (C) in forest and soybean as the percentage of gross precipitation, where $\mathrm{n}$ indicates the number of rainfall events sampled between 2008 and 2010 at each site. The medians of the datasets, displayed with black lines, and the 95\% confidence intervals around them, illustrated by notches, do not overlap. The surrounding boxes illustrate the interquartile range, while the whiskers reflect the extreme values within 1.5 times the interquantile range. Values exceeding this threshold are marked as outliers in the shape of an open circle.

The event-based comparison of stemflow, throughfall, and net precipitation between transitional forest and soybean fields differed significantly (Figure 8). The median stemflow 
(8.6\%) in soybeans was roughly 14 times higher than in the forest (0.2\%). On the other hand, throughfall results painted a different picture. The median throughfall in the forest was twice (81.7\%) as high as in the soybean field (40.2\%). Even after adding up throughfall and stemflow to calculate relative net precipitation this picture does not change; the median net precipitation was $79.1 \%$ and $52.3 \%$ in the forest and the soybean field, respectively.

\section{Discussion}

The negative exponential distribution of stem diameters was typical of an undisturbed forest with a small number of old-growth trees and a large number of younger trees (De Oliveira and Mori, 1999). Most stems were 5 to $10 \mathrm{~cm}$ dbh (57.1\%). Palms did not occur. The data were consistent with other forest inventory plots in the region (Balch et al., 2008; Ivanauskas et al., 2004). Mean measured LAI in the forest (4.8) was comparable with the LAI (5.0) documented in the forest $30 \mathrm{~km}$ distant from the site (Balch et al., 2008). LAI measured in the soybean site was consistent with results from the USA (Timlin et al., 2001) using the same methodology. Although the LAI of transitional forest was slightly higher than in the soybean plantation during its peak growth period (February and March), throughfall and net precipitation were significantly higher in the forest. According to Van Dijk and Bruijnzeel (2001), the storage capacity of canopies is linearly related to the LAI. In the present study, the difference of the mean LAI between soybean and forest was not sufficiently to explain on the difference in the net precipitation.

Throughfall and stemflow measured in the forest were similar to results of other throughfall studies in Amazonian forests (Table 4). Throughfall measured in the soybean field was similar to that measured by Bispo (2007) in Paragominas, another site in the Amazon Basin. He measured $54.1 \%$ of gross precipitation as throughfall under soybean cultivation between 42 and 114 days after sowing (Bispo, 2007). Further south in Brazil, Lilienfein and 
Wilcke (2004) reported more throughfall (76 - 89\%), which can be explained by the fact that the monitoring of the present study covered only the peak growth period while Lilienfein and Wilcke (2004) covered almost the entire growing season of a corn - soybean rotation.

Therefore, the higher throughfall quantities in soybean fields previously documented in the literature are due to the inclusion of theinitial growth period of soybeans when the canopy is not closed and from higher throughfall rates when corn rotations are included.

Table 4: Characteristics of experimental sites for throughfall (TF) and stemflow (ST) measurements in the Amazon Basin.

\begin{tabular}{llccl}
\hline Country & Site & TF [\%] & SF [\%] & Reference \\
\hline Brazil & Rancho Grande & 89.8 & 8.0 & Germer et al., 2006, 2010b \\
Brazil & Reserva Jaru & 87 & 1.4 & Ubarana, 1996 \\
Brazil & Res. Vale do Rio Doce & 86.2 & 0.8 & Ubarana, 1996 \\
Brazil & Reserva Ducke & 91 & 1.8 & Lloyd and de Marques Filho, \\
& & & & 1988 \\
Colombia & Pena Rocha & $82-87$ & $0.85-1.45$ & Tobón Marin et al., 2000 \\
Brazil & Rio Negro, Lake Prato & 78.5 & & Filoso et al., 1999 \\
Brazil & Bacia 3, Manaus & 92 & 2 & Cornu et al., 1998 \\
Brazil & Cuieiras Biological Reserva, Manaus & $74.8-87.6$ & $0.2-0.7$ & Cuartas et al., 2007 \\
Brazil & Bacia 3, Manaus & $81.2-87.1$ & & Ferreira et al., 2005 \\
Brazil & Scientific Station Ferreira Penna & 76.8 & 1.7 & Oliveira et al., 2008 \\
Brazil & Belem & 85 & 0.19 & Klinge et al., 2001 \\
Peru & La Cuenca & 83.1 & & Elsenbeer et al., 1994 \\
Brazil & Tapajos National Forest, Santarem & 88.4 & & Czikowsky, 2009 \\
Brazil & Tanguro Ranch & 91.6 & 0.69 & This study \\
\hline
\end{tabular}

The increasing amount of throughfall with larger rainfall events results from the fact that most of the interception storage is satiated early in a rain event (Lull, 1964). The bigger the rainstorm was the higher was the proportion of the precipitation reaching the ground via throughfall. Similar findings were reported for other tropical forests (Tobón Marin et al., 2000) as well as for soybean plantations in the Amazon Basin (Bispo, 2007). Throughfall did not have a consistent relationship with rainfall intensity, which is in line with results from other humid tropical sites (e.g., Elsenbeer et al., 1994; Hall, 2003). 
Stemflow behaved differently in the forest and soybean fields. As Lilienfein and Wilcke (2004) assumed, the stemflow fraction under soybean is high. This can be explained by the acute branching angles of the soybean leaves from the stem. Due to the high stem density in the soybean fields (270,000 stems/ha vs. 1392 stems/ha in the forest), basal areas in the forest and the soybean were comparable, so more stemflow was recorded per square meter in the soybean fields. The results from the stemflow measurements were lower than that documented for soybean in Lull (21\% of gross precipitation; 1964) and Bo et al. (23.7\% of gross precipitation as mean stemflow during a comparable growing period; 2008). Because stemflow collars effected soybean growth negative, there was a risk of leakage from the collars. So stemflow might be underestimated.

Nevertheless, stemflow as fraction of net precipitation contributed to a strong increase in net water input to the ground in the soybean field and emphasizes the importance of stemflow measurements in agricultural crops (Van Dijk and Bruijnzeel, 2001a). Throughfall measurements led to an underestimation of net precipitation by at least $9 \%$ in soybean fields, further emphasizing the need to incorporate more studies of stemflow. Stemflow in the transitional forest was low, similar to stemflow measurements in other Amazonian forests except for palm-rich open forests (Table 4). Most stemflow occurred on young smooth barked trees, where branches had acute angles funneling rainfall towards the stem. With an increase in age and dbh, branching angles also increased, leading to a reduction of the funneling effect and stemflow (Figure 7). Similar observations were reported by Germer et al. (2010b) in Terra Firme forest in the western Amazon. In general, the stemflow fraction of net precipitation in the forest was less than the rainfall measurement error, so it can be concluded that stemflow in transitional forest is negligible in water balance studies. 
The difference in net precipitation of $94.2 \%$ in transitional forest and $57.2 \%$ in soybean fields was large and higher than expected. This pattern also does not change if stemflow in soybean accounts for $21-24 \%$, as documented above. While in the forest net precipitation was insignificantly higher than throughfall, in soybean fields both throughfall and stemflow need to be taken into account for a realistic assessment of net precipitation. In the forest, the measurement period represented the majority of the rainy season (Figure $9 \&$ Table 2). The annual intercepted rainfall was less than that obtained by interception studies of Terra Firme forest (Cuartas et al., 2007) which can be explained by a lower LAI in transitional forest compared to Terra Firme forest. In soybean fields the measurement period was shorter and spanned only the 46 days of the height of the rainy season when the soybean crop was best developed. Because the soybean canopy was less developed in other times, net precipitation outside of the measurement period would almost certainly be higher. During the peak growth period for the soy, we found net precipitation to be $57 \%$ of gross precipitation. Even if net precipitation were $100 \%$ at other times, this still amounts to $140.5 \mathrm{~mm}$ of evaporated rainfall from soybean fields on an annual basis that is not typically accounted for in models and was higher than the annual intercepted water in the forest. Besides a potential underestimation of stemflow in soybean, there are two interacting mechanisms that may explain differences in net precipitation: one is vegetation characteristics (e.g. LAI, stem density, surface roughness of plants driven by species composition). The other explanatory mechanism is the micro-meteorological condition of each land cover. According to Van Dijk and Bruijnzeel (2001b), evaporation from wetted stems during storms can have a significant impact on interception loss, especially in low vegetation with strong within stand ventilation. While evaporation in soybean fields is higher than in the forest, evapotranspiration, the combined effect of evaporation from the surface and the active transpiration of plants, shows contrasting behavior and is higher in forests than soybean fields ( Berbet and Costa, 2003; Bispo, 2007; Pongratz et al., 2006; Sampaio et al., 2007). Pongratz et al. (2006) suggested a 
decrease in evapotranspiration from agricultural lands in Mato Grosso is caused by changes in the morphological structure of vegetation as well as an increase in canopy temperature and albedo. Sampaio et al. (2007) have shown an 18\% reduction of evapotranspiration from a $50 \%$ of conversion of forest to soybean fields in the eastern Amazon. Berbet and Costa (2003) also described a reduction of surface latent and sensible heat flux due to higher albedo as a consequence of land cover change from tropical forest to pasture in the Amazon Basin. Thus, evapotranspiration in soybean fields is less than in forest, while the proportion of evaporated rainfall is higher in soybeans. It follows that the observed differences in net precipitation between the forest and soybean fields in the present study can be partly attributed to differences in plant surface storage capacity, plant structure, stem density, and micrometeorological conditions caused by the homogenous structure of the soybean fields.

5 Soybean growth cycles and hydrological implications

Conclusions regarding the hydrological water balance of the Amazon are difficult to draw without net precipitation measurements capturing an entire year. Nevertheless, the differences in net water input to a watershed might be expected to decrease when the complete lifecycle of soybean is taken into account (Figure 9). In conditions like those found at the Tanguro Ranch where in the growing season of 2008-2009 no intermediate crop was planted, no interception will occur before the emergence of soybean in December. In response to the fast growth of soybean, interception increases until the maximum interception capacity is reached at the end of the rainy season. Typical practice at the Tanguro Ranch was to desiccate the mature crop before harvest; treated plants lose their leaves within a few days (pers. obs.). 

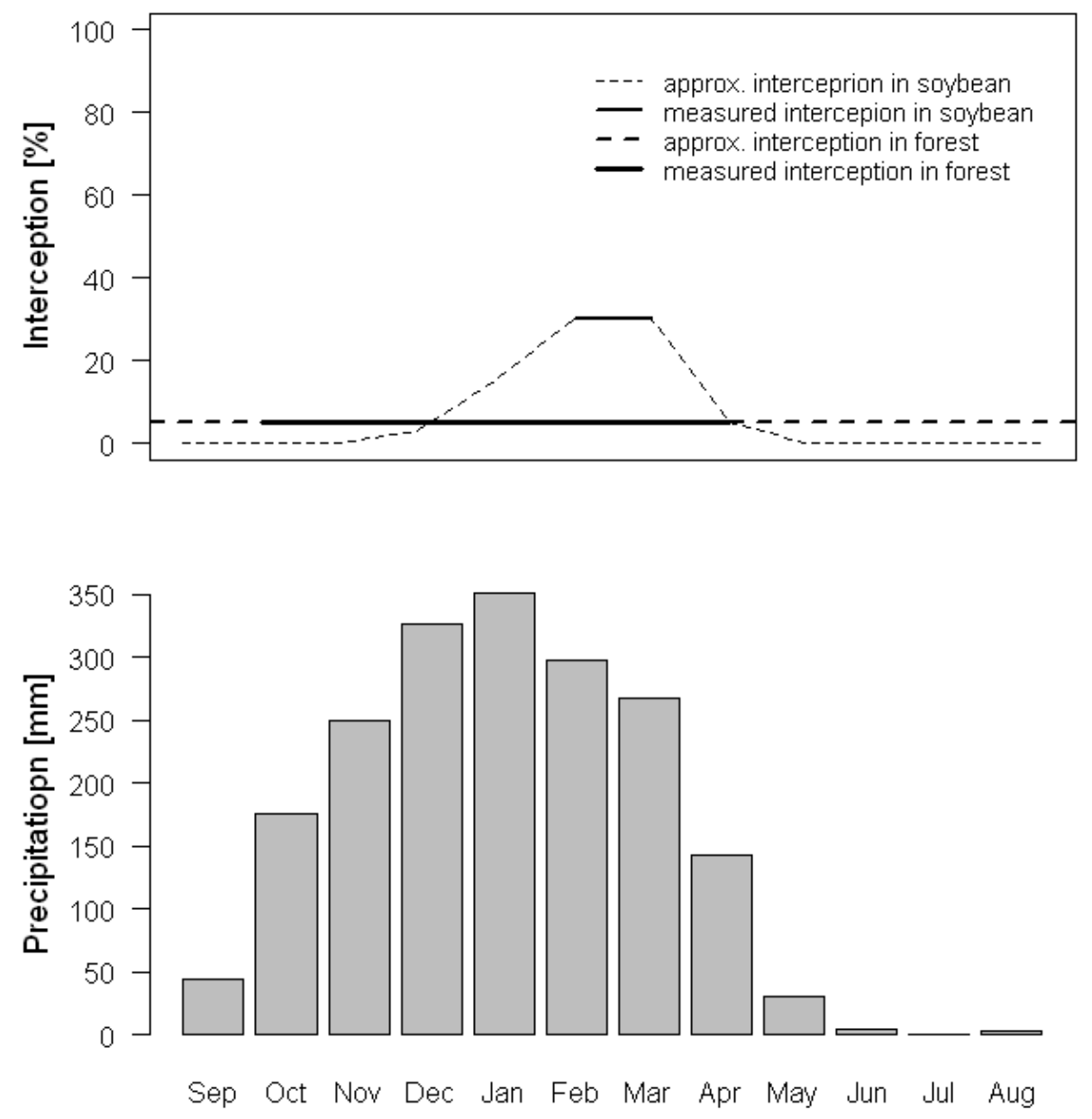

Figure 9: Interception behavior of tropical transitional forest and soybean fields throughout the year in respect to the annual rainfall distribution.

In the forest no changes in interception were observed throughout the rainy season, although a decline in the forest LAI during the dry season might decrease interception for occasional dry season rains. Taking the seasonality of precipitation into account (Figure 9, bottom), in which 95.6\% of the rainfall occurs between September and April, dry season interception probably has little influence on net water input. Based on the measured data from soybean fields, the net water input into the hydrologic system was found to be reduced by the presence of soybean fields. At the same time evapotranspiration of soybean fields was $30 \%$ less than in the forest, and runoff from watersheds planted with soybeans was more than fourfold that of forest watersheds (Hayhoe et al., 2011). By including the documented increase of 
daily runoff in the soybean in the hydrological analysis, a long-term reduction in water availability can be expected.

If current crop management trends in Mato Grosso continue, the effect of crop interception may increase over time. Galford et al. (2008) found that double-cropping of soybean with other crops (predominantly corn) increased by 49\% between 2001 and 2005. Double cropping means that crop cover would extend over more of the rainy season. Given that the area planted to soybean in Mato Grosso increased annually by $19.4 \%$ between 1999 2004 (Galford et al., 2008), multi-cropping could have a substantial effect on the long term water availability of the southern Amazon.

\section{Conclusions}

During the peak of soybean growth (February and March) in Mato Grosso, interception loss from soybean cropland was almost twice as high as in the original tropical transitional forest. Under soybean only $57.2 \%$ of the gross precipitation reaches the ground via stemflow and throughfall as against $94.2 \%$ under transitional forest. In contrast to transitional forest, soybean stemflow accounted for an important fraction of net precipitation. The observed differences in throughfall, stemflow, and net precipitation can be attributed to differences in plant structure and stem density. The homogenous structure of soybean allows a better within stand ventilation and enhanced within storm evaporation.

The measured throughfall, stemflow, and net precipitation were similar to those obtained in other Amazon forests studies, but values for soybean were lower than those found elsewhere. This is partly caused by the restricted sampling period during stabile canopy conditions but also may be due to an underestimation of stemflow resulting from the applied collection method. A vase method as used by Bo et al. (2008) and Van Dijk and Bruijnzeel (2001a) promise to give better results. 
The reduced net water input in soybean fields caused by interception is small compared to the differences in transpiration. But, in addition to the processes promoting a fast runoff reaction under soybean, interception contributes to reduced water availability in the long term. In view of the increasing tendency towards double-cropping practices at the southern edge of the Amazon Basin, crop interception will increase in importance in the calculation of water balances, and the hydrological impact analysis of land cover changes. The ratio of evaporation and transpiration changes due to deforestation, but more detailed research is necessary to describe the hydro-meteorological consequences of large-scale land cover changes.

\section{Acknowledgements}

This study was supported by grants from NSF (DEB-0640661), the Fundaçao de Amparo à Pesquisa do Estado de São Paulo (FAPESP 08/58089-9) and the German Academic Exchange Service (DAAD 50122036). We thank Shelby Riskin, Marcus Bauer, Janine Matthiessen, Karen van der Merve, Colette Henrichmann, Charlotte Wilzok and Rebekka Roller. We also thank Oswaldo Portella and the staff of the Instituto de Pesquisa Ambiental da Amazonia for the support in the fieldwork at Tanguro. Furthermore, we acknowledge Grupo A. Maggi for providing access to field sites and precipitation data. In addition, we thank Tara Massad for all the valuable comments.

\section{References}

Balch, J.K., Nepstad, D.C., Brando, P.M., Curran, L.M., Portela, O., De Carvalho, J.R., Lefebvre, P., 2008. Negative fire feedback in a transitional forest of southeastern Amazonia. Global Change Biology 14, 2276-2287.

Berbet, M.L.C., Costa, M.H., 2003. Climate change after tropical deforestation: seasonal variability of surface albedo and its effects on precipitation change. Journal of climate 16, 2099-2104.

Bispo, C.J.C., 2007. Balanco de agua em area de cultivo de soja no leste da Amazonica (Master Thesis). Belém.

Bo, M., Faqi, W., Fan, M., Mijing, Z., 2008. Effect of leaf area and rainfall intensity on the stemflow of Glycine max. Science of Soil and Water Conservation 6, 58-62. 
Brown, J.C., Koeppe, M., Coles, B., Price, K.P., 2005. Soybean production and conversion of tropical forest in the Brazilian Amazon: The case of Vilhena, Rondonia. AMBIO: A Journal of the Human Environment 34, 462-469.

Bui, E.N., Box, J.E., 1992. Stemflow, Rain Throughfall, and Erosion under Canopies of Corn and Sorghum. Soil Sciene Society of America Journal 56, 242-247.

CONAB (Companhia Nacional de Abastecimento), 2012. Agricultura e abastecimento em boa compania. Séries históricas. (last access: 17.05.2012). [WWW Document]. URL http://www.conab.gov.br/conteudos.php?a=1252\&t=2

Cornu, S., Ambrosi, J.P., Lucas, Y., Desjardins, T., 1998. Origin and behaviour of dissolved chlorine and sodium in Brazilian rainforest. Water Research 32, 1151-1161.

Costa, M.H., Foley, J.A., 1999. Trends in the hydrologic cycle of the Amazon basin. Journal of Geophysical Research. 104, 14,189-14,198.

Costa, M.H., Yanagi, S.N.M., Souza, P.J.O.P., Ribeiro, A., Rocha, E.J.P., 2007. Climate change in Amazonia caused by soybean cropland expansion, as compared to caused by pastureland expansion. Geophysical Research Letters 34, L07706.

Crockford, R.H., Richardson, D.P., 1990. Partitioning of rainfall in a eucalypt forest and pine plantation in southeastern Australia: II stemflow and factors affecting stemflow in a dry sclerophyll eucalypt forest and a pinus radiata plantation. Hydrological Processes 4, 145-155.

Cuartas, L.A., Tomasella, J., Nobre, A.D., Hodnett, M.G., Waterloo, M.J., Múnera, J.C., 2007. Interception water-partitioning dynamics for a pristine rainforest in Central Amazonia: marked differences between normal and dry years. Agricultural and Forest Meteorology 145, 69-83.

Czikowsky, M.J., 2009. Observations of the transient characteristics of the hydrological balance. Thesis (Ph.D.). State University of New York at Albany.

Czikowsky, M.J., Fitzjarrald, D.R., 2009. Detecting rainfall interception in an Amazonian rain forest with eddy flux measurements. Journal of Hydrology 377, 92-105.

De Moraes, J.M., Schuler, A.E., Dunne, T., Figueiredo, R.O., Victoria, R.L., 2006. Water storage and runoff processes in plinthic soils under forest and pasture in Eastern Amazonia. Hydrological Processes 20, 2509-2526.

De Oliveira, A.A., Mori, S.A., 1999. A central Amazonian terra firme forest. I. High tree species richness on poor soils. Biodiversity and Conservation 8, 1219-1244.

Dezzeo, N., Chacón, N., 2006. Nutrient fluxes in incident rainfall, throughfall, and stemflow in adjacent primary and secondary forests of the Gran Sabana, southern Venezuela. Forest Ecology and Management 234, 218-226.

Elsenbeer, H., Cassel, D.K., Zuniga, L., 1994. Throughfall in the Terra Firme forest of Western Amazonia. Journal of Hydrology (NZ) 32, 30-45.

Eltahir, E.A.B., Bras, R.L., 1994. Precipitation recycling in the Amazon basin. Quarterly Journal of the Royal Meteorological Society 120, 861-880.

Filoso, S., Williams, M.R., Melack, J.M., 1999. Composition and deposition of throughfall in a flooded forest archipelago. Biogeochemistry 45, 169-195.

Galford, G.L., Mustard, J.F., Melillo, J., Gendrin, A., Cerri, C.C., Cerri, C.E.P., 2008. Wavelet analysis of MODIS time series to detect expansion and intensification of row-crop agriculture in Brazil. Remote Sensing of Environment 112, 576-587.

Germer, S., Elsenbeer, H., Moraes, J.M., 2006. Throughfall and temporal trends of rainfall redistribution in an open tropical rainforest, south-western Amazonia (Rondônia, Brazil). Hydrology and Earth System Sciences 10, 383-393.

Germer, S., Neill, C., Krusche, A.V., Elsenbeer, H., 2010. Influence of land-use change on near-surface hydrological processes: undisturbed forest to pasture. Journal of Hydrology 380, 473-480.

Germer, S., Werther, L., Elsenbeer, H., 2010. Have we underestimated stemflow? Lessons from an open tropical rainforest. Journal of Hydrology 395, 169-179.

Hall, R.L., 2003. Interception loss as a function of rainfall and forest types: stochastic modelling for tropical canopies revisited. Journal of Hydrology 280, 1-12.

Hasler, N., Avissar, R., 2007. What controls evapotranspiration in the Amazon Basin? Journal of Hydrometeorology 8, 380-395. 
Hayhoe, S.J., Neill, C., Porder, S., McHorney, R., LeFebvre, P., Coe, M.T., Elsenbeer, H., Krusche, A.V., 2011. Conversion to soy on the Amazonian agricultural frontier increases streamflow without affecting stormflow dynamics. Global Change Biology 17, 1821-1833.

Hutyra, L.R., Munger, J.W., Nobre, C.A., Saleska, S.R., Vieira, S.A., Wofsy, S.C., 2005. Climatic variability and vegetation vulnerability in Amazonia. Geophysical Research Letters 32, L24712.

Ivanauskas, N.M., Monteiro, R., Rodrigues, R.R., 2004. Structure of patch of Amazonian forest in the alto rio Xingu basin. Acta Amazonica 34, 275-299.

Jetten, V.G., 1996. Interception of tropical rain forest: performance of a canopy water balance model. Hydrological Processes 10, 671-685.

Klinge, R., Schmidt, J., Fölster, H., 2001. Simulation of water drainage of a rain forest and forest conversion plots using a soil water model. Journal of Hydrology 246, 82-95.

Köppen, W., 1936. Das geographische System der Klimate. Handbuch der Klimatologie. Gebrüder Borntraeger, Berlin.

Lamm, F.R., Manges, H.L., 2000. Partitioning of sprinkler irrigation water by a corn canopy. Transactions of the American Society of Agricultural Engineers 43, 909-918.

Lawrence, D.M., Thornton, P.E., Oleson, K.W., Bonan, G.B., 2007. The partitioning of evapotranspiration into transpiration, soil evaporation, and canopy evaporation in a GCM: impacts on land-atmosphere interaction. Journal of Hydrometeorology 8, 862880.

Lilienfein, J., Wilcke, W., 2004. Water and element input into native, agri-and silvicultural ecosystems of the Brazilian savanna. Biogeochemistry 67, 183-212.

Lima, W.P., Nicolielo, N., 1983. Precipitaçao efetiva e interceptaçao em florestas de pinheiros tropicais e em reserva de cerradao. Revista Scientia Forestalis 43-46.

Lloyd, C.R., de O. Marques Filho, A., 1988. Spatial variability of throughfall and stemflow measurements in Amazonian rainforest. Agricultural and Forest Meteorology 42, 6373.

Lull, H.W., 1964. Ecological and silvicultural aspects, in: Handbook of Applied Hydrology. Chow, V.T., New York, pp. 6.6-6.13.

Macedo, M.N., DeFries, R.S., Morton, D.C., Stickler, C.M., Galford, G.L., Shimabukuro, Y.E., 2012. Decoupling of deforestation and soy production in the southern Amazon during the late 2000s. Proceedings of the National Academy of Sciences 109, 1341-1346.

Marengo, J.A., 2006. On the hydrological cycle of the Amazon Basin: A historical review and current state-of-the-art. Revista Brasileira de Meteorologia 21, 1-19.

Marimon, B.S., De S. Lima, E., Duarte, T.G., Chieregatto, L.C., Ratter, J.A., 2006. Observations on the vegetation of northeastern Mato Grosso, Brazil. IV. An analysis of the Cerrado - Amazonian forest ecotone. Edinburgh Journal of Botany 63, 323341.

Morton, D.C., DeFries, R.S., Shimabukuro, Y.E., Anderson, L.O., Arai, E., del Bon EspiritoSanto, F., Freitas, R., Morisette, J., 2006. Cropland expansion changes deforestation dynamics in the southern Brazilian Amazon. Proceedings of the National Academy of Sciences 103, 14637-14641.

Oliveira, L.L., Ferreira da Costa, R., Sousa, F.A.S., Costa, A.C.L., Braga, A.P., 2008. Net precipitation and interception in Caxiuana, in the Eastern Amazonia. Acta Amazonica 38, 723-732.

Pongratz, J., Bounoua, L., DeFries, R.S., Morton, D.C., Anderson, L.O., Mauser, W., Klink, C.A., 2006. The impact of land cover change on surface energy and water balance in Mato Grosso, Brazil. Earth Interactions 10, 1-17.

RADAM, 1981. Levantamento de Recursos Naturais, Vol. 25, Mapa Exploratório de Solos, Goiás, Folha SD 22, Projecto RADAM Brazil.

Sampaio, G., Nobre, C., Costa, M.H., Satyamurty, P., Soares-Filho, B.S., Cardoso, M., 2007. Regional climate change over eastern Amazonia caused by pasture and soybean cropland expansion. Geophysical Research Letters 34, L17709.

Savabi, M.R., Stott, D.E., 1994. Plant residue impact on rainfall interception. Transactions of the American Society of Agricultural Engineers 37, 1093-1093. 
Timlin, D., Pachepsky, Y., Reddy, V.R., 2001. Soil water dynamics in row and interrow positions in soybean (Glycine max L.). Plant and Soil 237, 25-35.

Tobón Marin, C., Bouten, W., Sevink, J., 2000. Gross rainfall and its partitioning into throughfall, stemflow and evaporation of intercepted water in four forest ecosystems in western Amazonia. Journal of Hydrology 237, 40-57.

Ubarana, V.N., 1996. Observations and modelling of rainfall interception at two experimental sites in Amazonia. Gash, JHC; Nobre, Carlos Alfonso; Robert, JM; Victoria, RL (eds.). Amazonian deforestation and climate. 151-162.

Van Dijk, A., Bruijnzeel, L.A., 2001a. Modelling rainfall interception by vegetation of variable density using an adapted analytical model. Part 1. Model description. Journal of Hydrology 247, 230-238.

Van Dijk, A., Bruijnzeel, L.A., 2001b. Modelling rainfall interception by vegetation of variable density using an adapted analytical model. Part 2. Model validation for a tropical upland mixed cropping system. Journal of Hydrology 247, 239-262.

Welles, J.M., 1990. Some indirect methods of estimating canopy structure. Remote Sensing Reviews 5, 31-43.

WWF, 2012. WWF - US: World Wildlife Fund - Ecoregions [WWW Document]. URL http://www.worldwildlife.org/wildworld/profiles/terrestrial_nt.html

Zhang, L., Dawes, W.R., Walker, G.R., 1999. Predicting the effect of vegetation changes on catchment average water balance (Technical Report). Cooperative Research Center for Catchment Hydrology. 